\title{
Development of Problem-Based Mathematics Learning Tool to Train the Creativity of Learners on the Number of Assessment Materials and Difference between Two Fraction in Grade IV Elementary
}

\author{
Agus Astini ${ }^{1)}$, Agung Lukito ${ }^{2)}$, Tatag Yuli Eko Siswono ${ }^{3)}$ \\ ${ }^{1)}$ Elementary Education, Pascasarjana, Universitas Negeri Surabaya \\ 2) Faculty of Mathematics and Science Universitas Negeri Surabaya, Indonesia \\ ${ }^{3)}$ Faculty of Mathematics and Science Universitas Negeri Surabaya, Indonesia
}

\begin{abstract}
The purpose of this study was to describe the results of the development of problem solving-based mathematics learning tools to train the creativity of students on estimating the amount and difference of two fractions in grade IV SD Khadijah. The development of learning tools in this study uses the Thiagarajan 4D model which is modified into 3D, namely the define stage, the design stage, the development stage. Learning tools developed include RPP, LKPD, and TKPD. The instruments used were the learning device validation sheet, the teacher and student activity observation sheet, the student's creativity test, and the learning outcome assessment. After the data were analyzed descriptively, the results of the study were as follows: the average value of the RPP was 3.79 , the validity value of the LKPD was 3.50, and the results of the TKPD validation could be used with minor revisions. So that the learning device is said to be valid. The teacher's activities in implementing problem-solving learning have been good because all the learning steps in the lesson plan have been carried out. The activities of students while participating in learning at meeting 1 and meeting 2 have increased. With an increase in the activity of students it means that students are active in participating in problem solving-based mathematics learning. The students' creativity test was given two tests, namely before and after problem-solving based learning. The results of the creativity tests of students before and after problem solving based learning were $37.8 \%$ and $57.9 \%$. Thus, the creativity of students has increased significantly after using problem-solving based learning tools.
\end{abstract}

Keywords:- Problem solving based learning, creativity, estimation of the number and difference of two fractions.

\section{INTRODUCTION}

Along with the rapid development of the times, the problems of life facing humans are also more complex, so it demands people to think creatively. Especially with the development of science.

Laptops, Mobile, Note book, I-pad, even child watches that are now booming are creative people's creativity. Creative thinking skills need to be developed to help solve problems, and look for troubleshooting alternatives. One of the efforts that can be done to develop these skills is through education.

Education at this time should establish learners who can face globalization, environmental issues, progress in information technology, science and technology, the emergence of creative industries, and the influence and impact of technology. Students must be equipped with creative thinking skills for lifelong learning, learning from various sources, learning to work together, adapting, and resolving problems. Therefore, the traditional learning paradigm that focuses more on material mastery must be changed in such a way that it can be used to prepare students for competing in the future.

The importance of developing creative thinking skills is poured in national education objectives, which is to develop the potential of learners to become human beings who believe and obey God Almighty, be noble, healthy, knowledgeable, capable, creative, independent, and be a democratic citizen and responsible. (Act No. 20 of year 2003 article 3 on the National education system).

Regulation of the Minister of Education and Culture No. 20 of 2016 about the standards of competency of primary and secondary education explained that primary/secondary school graduates have behaviors that reflect the attitude of faith and knowledge to the Almighty God, characteristic, honest, caring, responsible, lifelong learners, healthy physically and spiritually. Graduates are expected to have factual, conceptual, procedural, and metakognitive knowledge at the ground level with regard to 
science, technology, art, and culture. More than that they also have creative thinking and acting skills, productive, critical, independent, collaborative, and communicative.

Basic education is an educational level that serves as the foundation of early scholarly education. Therefore, learning in elementary school should be adjusted to the stage of the child's development at that time. To elementary school children should be given experience as well as opportunities to develop creative thinking skills to solve problems so that appears creativity. But reality in the field, the various subjects learned students more often just by memorizing. A pattern of monotonous teacher learning and less variative. The learning strategies that run less involve learners consistently and in real. Learners feel less confident in their own work in the application of mathematical materials on daily life.

The practice of learning is certainly less in line with the National Education Standards (Permendikbud number 22 year 2016 on the standard of the process) mentioning that the learning process in the education unit is organized interactively, inspiring, fun, challenging, motivating learners to actively participate, and providing ample space for initiatives, creativity, and independence in accordance with the talents, interests, and physical development of

To overcome these problems, innovative learning is required by teachers to develop learning objectives. and the handling of the students ' creative thinking skills can be intergrated in each lesson because learners are the human resources needed for the development of the nation and state in the future.

Creative thinking is a process that is used when one individual brings or raises a new idea. By familiarizing learners doing problem solving, the logical power, creativity, and critical thinking power can be increased. Moreover, today the government has used the 2013 curriculum in the hopes that students can demonstrate their thinking skills, strengthening their creativity that can be used in the future and in their workforce later in the day.

Slameto (2010:145) Explaining creativity is a term that is widely used both in the school environment and outside the school. In fact, the creative sense relates to the discovery of something that produces something new by using something that already exists.

This creativity is an important component and it is necessary. Without student creativity will only work on a narrow cognitive level. The creative aspect of the brain can help explain and interpret abstract concepts, allowing the child to achieve more mastery, especially in mathematical subjects that are often difficult to understand.

In creativity, teachers can use different approaches to learning that will encourage problem solving and investigation, awaken children's natural curiosity and desire to learn. In addition, the creative approach can also help the child to raise ideas when the imagination is included. A sizable curiosity will affect the child's creativity, they will always want to try something new that if they are new to learning it.

Teachers, students, and teaching materials are the dominant elements of the learning process. A number of materials, tools, media, hints and guidelines to be used in the mathematics learning process is a learning tool for mathematics. The devices in the English dictionary are interpreted as equipment, while learning is a planned effort in manipulating learning resources so that the learning process occurs in students (Sadiman DKK,2002:7). While Trianto (2007:68) states that learning devices are the devices used for the learning process.

Learning devices are a collection of learning resources that allow teachers and students to perform learning activities to achieve their learning objectives. The learning devices developed in this study are: the study Implementation Plan (RPP), the Student activity sheet (LKPD), the Assessment of Learning Outcomes (PHB). Good quality learning tools are learning devices that meet valid, practical, and effective criteria. Learning devices are declared valid when learning devices meet the validity and validity of a construction determined by the experts and are legally acceptable. Learning tools are said to be practical when experts declare that the devices that are developed can be applied in the field, well carried out learning, teacher skills in managing good learning, welldesigned student activities, learning tools are said to be effective when learners ' outcomes are completed in a classical way (at least 70\%).

Learning tool development is a process for generating learning devices. The development of learning devices conducted in this research refers to the model of development of Thiagarajan, Semmel and Sammel (1974:6) consisting of four stages namely the definition (define), the design phase, the development stage (development), and the phase of dissemination (disseminate). But the development of learning in this study is limited to the development phase.

Problem solving is an approach by identifying the problem to the planning phase of completion and then analyzed that is sorting the whole problem so that it reaches the application stage then check back to get the solution in solving the problem. Problem solving is very important in the learning process. Problem-based learning aims to allow students to face changing circumstances in an everexpanding world, through exercises acting on the basis of logical, rational, critical, thorough, honest, and effective thinking. Problem-based learning is a learning that helps learners understand and master learning materials by implementing troubleshooting steps. In this study the troubleshooting steps used are troubleshooting steps according to Polya 
Problem solving is taught explicitly to be the goal of learning mathematics and is contained in the mathematical curriculum, because problem solving has benefits, namely (1) developing cognitive skills in general, (2) Encouraging creativity, (3) problem solving is part of the mathematical application process, and (4) motivating learners to learn mathematics (Pehkonen, 1997). According to Rahmawati (2010) Problem solving is the process of applying the previously acquired knowledge into a new situation that is not yet known. Problem solving is one of the learning models that can be used to train the creativity of learners. In the context of learning, to know whether the child can think creatively or not, it takes criteria that can measure the levels of creative thinking skills.

Fractions are one form of numbers that can be expressed as $\mathrm{P} / \mathrm{Q}$, with $\mathrm{P}$ and $\mathrm{q}$ being integers and $\mathrm{q} \neq 0$. The number $\mathrm{p}$ is called a number and $\mathrm{q}$ is called a denominator. We often find fractions in the map there are 1:200000 posts, items in stores or supermarkets with pieces of price at $20 \%, 50 \%$, or others. Fractional material in class IV SD is to recognize and understand the concept of fractional fractions and perform fractional calculating operations using concrete or image objects, converting a fraction into different forms of fractional, determining the outcome of the summation calculate operation and reduction of fractional forms. In this study focused on the summation material and the reduction of various forms of fractional.

Given the importance of creative thinking, it is necessary to devise a learning model that can train the creativity of learners. One of the mathematical learning models that give space to educate learners ' creativity is a problem-based learning solution. In problem-based learning, students ' creativity can be trained, so the learning is fun, so the research is proposed: "Development of mathematics-based learning device troubleshooting to train creativity of learners on the number and difference assessment material of two fraction in class IV SD".

\section{METHOD}

\section{Types of research}

This research aims to develop learning devices that will then be implemented in the classroom so that the research is categorized as development research. In accordance with this, development research was conducted to produce a learning device for mathematics with a problem-solving model to train students ' creativity in the assessment material of the sum and difference of fractional in grade IV elementary School. The learning devices developed in this study include: Learning Implementation Plan (RPP), Student Worksheets (LKPD), and Learning Outcomes Assessment (PHB).

\section{Time and place of research}

This research was held in class IV students at SD Khadijah Jl. A. Yani No. 2-4 Wonokromo Subdistrict, the private school of Islam, is open and responsive in efforts to update constructive learning activities.

\section{$>$ Subjecresearch}

The subjects in this study were students of class IV SD Khadijah who numbered 30 learners, trials were used to see the creativity of learners from the use of problem-based math learning devices.

\section{$>$ Design Research}

In this development study, researchers used the theory of four D models Thiagarajan, et al. Determination and determination of the implementation of the theory because the stages used are sequential and easy to implement. The development of model four D models developed by Thiagarajan, Semmel, and Semmel 1974) covers four stages of development, namely define, design, develop, and disseminate or adapted into 4-P models, namely definition, design, development, and dissemination. In the implementation, researchers use this model in only 3 phases: Define, design, and develop. For the fourth stage is disseminate not done by researchers in this research. Researchers do not implement this stage due to several considerations, such as:

- Cost factor. More and more research places will increase the cost needed by researchers. This is an obstacle and a contributing factor so that the research is only done as a sample.

- Time. If the fourth step is carried out thoroughly as the concept of the 4D development, then the time required by the researcher is also longer, and this also complicate researchers because it must be really focused and spend a special time to implement it. Researchers are aware of the limitations and deficiencies that are actually a weakness in this study. However, researchers have tried to optimally train the creativity of class IV students in elementary school, especially in the assessment material of the number and difference of two fraction by using a problem solving based math learning tool.

\section{Collecting Techniques}

The collection of data in this study was conducted on learning activities using a problem-based learning model to train the students ' creativity in the assessment material of the number and difference of two fractions in class IV SD. Data collection is conducted through:

\section{- Tes}

Tests are given after learning. The goal is to know the level of understanding and knowledge of learners following learning. Researchers use the instrument in writing of test questions and in the form of a description containing questions about the assessment material of the number and difference of two fragments.

\section{- Observation}

Observations were conducted to observe the teacher's activities and students ' activities during the learning process. The instrument used is the observation sheet of teacher activity and the activity of learners. 


\section{- Analysis of Learning Effectiveness Data}

The effectiveness of learning can be known from learning outcomes, teachers ' ability to manage learning, and the activities of learners.

\section{- Analysis of learning outcomes Data}

Learning is said to be effective when student learning outcomes are completed individually and classifications.

$\checkmark$ Complete individually

When the student's learning results have a minimum value of 75 based on the value of the KKM from the value range $0-100$

$\checkmark$ The classical is complete

$\checkmark$ If at least $70 \%$ of the number of learners in the class of learning results complete.

\section{$>$ Analysis of teacher activity data}

Learning is said to be effective when the teacher's activity when learning takes a minimum of good grades for each observed component.

\section{Analyze student activity data}

Learning is said to be effective when the students ' activities when learning takes a minimum of good grades for each observed component. As for measuring students ' learning outcomes, the study was developed:

- Assessment of learning outcomes

The study results test is a test item used to determine the learning outcomes of learners after joining Trianto's teaching and learning activities (2011:235). According to Hamiyah (2014:112) The test of learning results is a tool arranged to reveal the extent to which learners have achieved pre-defined teaching objectives. In addition, to gain a measure of the effectiveness of test instruments based on their influence on learning, the teacher must give the same test before and after the lesson. Based on the explanation above, researchers conclude that the study results test is a tool that is structured to know the learning outcomes of learners after the study activities and a test is said to be good if the test is eligible, and reliable

\section{- Student Learning outcomes}

Learning submission is the level of competency achievement after learners follow the learning. Learners are said to complete individual study if they get a value of $\geq 75$ of the maximum value of 100 and a class is said to complete the classical learning if $\geq 70 \%$ of learners have achieved individual survival.

\section{RESULTS AND DISCUSSION}

\section{A. Learning tool Development process}

This research uses the development phase of the 4D model that has been modified into 3D. The learning devices developed are RPP, LKPD, and TKPD. The development of quality learning devices must meet the criteria of validity, practicality, and effectiveness. Validating information obtained from the validation results of learning devices in the form of RPP, LKPD, and TKPD by the validator. Practicality is derived from the observation of the field of teacher and student activity based on RPP that has fulfilled the criteria of validity. The effectiveness is obtained from TKPD (pre-Test and post-test).

\section{B. Learning Tool Development Results}

Discussion of learning device development data and teaching device quality is described as follows:

\section{Learning Implementation Plan (RPP)}

Based on the analysis of the validation results in the 4.5 table which gets the average value at least 3 for each aspect. So in general the assessment of the validator against RPP gives the conclusion that RPP deserves to be implemented.

\section{$>$ Learners 'Worksheets (LKPD)}

Based on analysis of the validation results in the 4.7 table, it is known that there are two LKPD that have been developed for two meetings. The contents of LKPD include fractional assessment material. LKPD-1, which was developed by researchers on the assessment of fractional summation results. LKPD-2 contains the assessment of fractional difference results. Students work on LKPD in groups that are arranged heterogeneous. During the two meetings the students trained his creativity through working on the LKPD in groups. LKPD validation results obtained the data that the category LKPD is good and declared worthy to be implemented.

\section{Learners ' Creativity Test (TKPD)}

TKPD analysis based on the validation results in the 4.9 table shows that the TKPD is suitable to train the creativity of learners. This can be known from the component of the criteria of creativity, which includes smoothness, flexibility, and novelty. There are 12 creative learners, and 17 creative enough as well as 2 less creative learners.

\section{Teacher activities in implementing problem-based mathematical learning}

Teacher activity in implementing problem solving learning is good because all the learning steps in RPP have been done. According to the table 4.13, there are observations that the teacher's activity in implementing problem-based learning has a minimum score of 3 out of some aspects and scores 4 on several other aspects. This shows that the results of observing teacher activity have fulfilled the criteria of effectiveness in delivering learning.

\section{Student activities While following problem-based math learning}

Student activities while following the learning at meeting 1 and meeting 2 have increased. Like students ' readiness to follow learning and listening to teachers when communicating learning objectives, receiving feedback and guidance from teachers to work more actively in completing the tasks in the LKPD, as well as concluding learning that has been learned with the guidance of the teacher has already received a score of 2 and at the next meeting the learners have a score of 3 . With the increase in student activity, it means that students are active in 
following problem-based mathematical learning. The more active the learners are the more effective the learning is.

\section{The effectiveness of learning}

The effectiveness of learning can be seen from the results of student creativity test and student learning outcomes. Based on the students ' learning outcomes in the 4.19 table showed that students ' learning outcomes using low-category problem-based math learning devices were 4 learners with a percentage of $12.9 \%$, being 12 students with a percentage of $38.7 \%$ and a high category of 15 students with a percentage of $48.4 \%$. TKPD analysis based on the validation results in the 4.9 table shows that the TKPD is suitable to train the creativity of learners. This can be known from the component of the criteria of creativity, which includes smoothness, flexibility, and novelty. In this study 12 learners included creative, and 17 learners included creative enough.

\section{Student Creativity Level Discussion}

According to the 4.15 table, it can be noted that student creativity increases after learning activities with problem-based math learning devices. The following in the show recapitulation results $\mathrm{N}$-Gain creativity of learners based on the less creative category, quite creative and creative. The results obtained when viewing the table 4.16 show that the creativity of learners using a problem-based, less creative, learning-driven math lesson there are 2 learners with a percentage of $6.5 \%$, a category quite creative 17 students with a percentage of $54.8 \%$ and creative category 12 students with a percentage of $38.7 \%$. Thus, the creativity of learners experienced a significant improvement after using a troubleshooting-based learning tool.

\section{E. Reflection Research}

This research has a weakness that is in terms of data collection. In data collection techniques, Penliti has not used a poll of students. The awarding of the students should be done to find out the response from the subject. Researchers should share a student response poll that contains about student responses after learning so that researchers can learn that learners are happy and challenged in the problem-based learning process. The results can strengthen the effectiveness of problem-based mathematical learning devices. Documentation taken during research is only limited to images, without accompanying documentation in the form of video.

\section{CONCLUSION}

Based on the research results, it can be taken as a conclusion:

Using a modified 4-D model, it has been generated a problem-based math learning tool in the form of RPP, LKPD, TKPD for the number of assessment material and the difference between two pieces that meet the good criteria. It is indicated by: (a) The resulting device is valid; (b) The ability of teachers to manage learning well; (c) effective student activities; (d) The learner's creativity test is valid, reliable, and sensitive.
Each problem-based mathematical learning tool developed in this study has been assessed as valid by experts with the average validity of RPP 3.79, LKPD 3.50. So learning devices are said to be valid.

$>$ Problem-based learning devices can train students ' creativity well-judged for each learning device, meaning that developed learning devices can be used with fewer revisions.

$>$ The results of the student creativity Test at SD Khadijah through the study of mathematical-based problemsolving material and the difference between two fragments can be said to be creative.

\section{SUGGESTION}

Based on the research that has been conducted, the researcher gave a thought contribution to the development of learning devices, especially mathematics as follows:

$>$ Effective problem-solving-based learning to teach fractional assessment material, so it can be applied to teach other materials.

$>$ Problem-based learning can be used as an alternative learning in the effort to train the creativity of learners.

$>$ Students are given an open question on every math lesson, so that students are accustomed to working on open matter so that the creativity of trained learners

$>$ In order for LKPD to be used easily by learners, teachers should know the characteristics of the students ' self-development. Don't let the teachers make the LKPD because it is too difficult for learners to understand. So the learners are not able to solve the problem.

$>$ A problem-based math learning tool to train the creativity of these learners should be tested also on other classes or schools so that a better learning device is obtained.

\section{REFERENCES}

[1]. Al-Silami, T. A. (2010). A Comparison of Creative Thinking and Reflective-Impulsive Style in Grade 10 Male Students from Rural and Urban Saudi Arabia. Dissertation of Doctor of Philosophy, Victoria University, Download 23 Nop 14.

[2]. Arifin, Z. (2010). Membangun Kompetensi Pedagogis Guru Matematika. Surabaya: Lentera Cendikia.

[3]. Arikunto, S. (2013). Dasar-dasar Evaluasi Pendidikan (Edisi Revisi). Bandung: Bumi Aksara.

[4]. Byron, Kevin. (2006). Creative Problem Solving. Artikel online diakses di http://www.wooster.edu/teagle/docs/byron\%20Creativ e\%20problem\%20Solving.pdf pada 23 Nop 13.

[5]. Depdiknas, 2003. Undang-undang Republik Indonesia No 20 tahun 2003 tentang Sistem Pendidikan Nasional. Jakarta: Depdiknas.

[6]. Depdiknas.(2006). Standar Isi Mata Pelajaran Matematika SD/MI, Jakarta: Depdiknas.

[7]. Depdiknas.(2008a). Panduan Pengembangan Bahan Ajar, Jakarta: Direktorat Pembinaan SMA, Dirjen Mandikdasmen, Depdiknas. 
[8]. Depdiknas, (2008b). Peraturan Menteri Pendidikan Nasional RI Nomor 2 Tahun 2008 Tentang Buku, Jakarta: Depdiknas.

[9]. Djamarah, S. (2005). Guru dan Anak Didik Dalam Interaksi Edukatif Suatu Pendekatan Teoritis Psikologis, Jakarta: Rineka Cipta.

[10]. Eragamreddy, (Nieven, 1999) Nagamurali, 2013. Teaching Creative Thinking Skills, Libya: Faculty of Education, Traghen, The University of Sebha

[11]. Filsaime, Dennis K, 2008, Menguak Rahasia Berpikir Kritis dan Kreatif. Jakarta :Prestasi Pustaka

[12]. Hamiyah Nur, Jauhar. Mohammad. (2014). Strategi Belajar Mengajar di Kelas. Jakarta:Prestasi Putaka

[13]. Herman, Tatang. (2007). Pembelajaran Berbasis Masalah untuk Meningkatkan Kemampuan Berpikir Matematis Tingkat Tinggi Siswa Sekolah Menengah Pertama, Jurnal Educationist No. I Vol. I Januari 2007.

[14]. Hudojo, Herman. (2001). Pengembangan Kurikulum Pembelajaran Matematika, Malang: JICA

[15]. Jumriah. (2012). Penerapan Pembelajaran Kooperatif dengan Pendekatan Pemecahan Masalah untuk Meningkatkan Kemampuan Berpikir Kreatif Matematika Siswa Kelas IV. Makalah Koprehensif Magister Pendidikan, Universitas Negeri Surabaya.

[16]. Kandemir, Mahmet Ali, GUR, Hulya. (2007). Creativity Training in Problem Solving: A Model of Creativity in Mathematics Teacher Education. Jurnal penelitian di New Horison in Education Turkey

[17]. Khanafiyah, S. (2010). Penerapan Pendekatan Modified Free Inquiry Sebagai Upaya Meningkatkan Kreativitas Mahasiswa Calon Guru Dalam Mengembangkan Jenis Eksperimen Dan Pemahaman Terhadap Materi Fisika. Jurnal berkala fisika, Vol 13 No 2, pp e\&-e17.

[18]. Kim, K.H. (2011). The Creativity Crisis:The Decrease in Creative Thinking Score on The Torrance Tests of CreativeThinking. Northwestern: Routledge

[19]. Marzano, Robert J. (1988). Dimensions of Thinking: A Framework for Curriculum and Instruction, Virginia: ASCD

[20]. Munandar, Utami. (2002). Pengembangan Kreativitas Anak Berbakat. Jakarta: Rineka Cipta

[21]. Nieveen, N. (1999). Design Approaches and Tools in Education and Training. Netherlands: Kluwer Accademy, 127.

[22]. Nur, Mohamad. (2011). Model Pembelajaran Berdasarkan Masalah, Surabaya: Pusat Sains dan Matematika Sekolah Unesa.

[23]. Pehkonen, E. (1997). Number 3. Dipetik September, 2013, dari www.fiz.karlsruhe.de/fiz/publications/zdm.

[24]. Rachmawati, Y. \& Kurniati, E. (2010). Strategi Pengembangan Kreativitas Pada Anak Usia Taman Kanak-Kanak. Jakarta: Kencana Prenada Media Group.

[25]. Rahmawati, T.D. (2010). Kompetensi Berpikir Kritis dan Kreatif Dalam Pemecahan Masalah Matematika di SMP negeri Malang. tanti_06320105@yahoo.co.id

[26]. Sani, Abdullah Ridwan. (2014). Pembelajaran Saintifik untuk Implementasi Kurikulum 2013. Jakarta: PT Bumi Aksara.
[27]. Semiawan, C. (1997) Prespektif Pendidikan Anak Berbakat. Jakarta: Gramedia Widiasarana Indonesia

[28]. Silver, E.A.(1997,June). Number 3. $\underline{\text { www.fiz }}$ karlsruhe.de/fiz//publications/zdm.

[29]. Siswono, Tatag Yuli Eko. (2008). Model Pembelajaran Matematika Berbasis Pengajuan dan Pemecahan Masalah untuk Meningkatkan Kemampuan Berpikir Kreatif, Surabaya: Unesa University Press.

[30]. Slameto, (2010). Belajar \& Faktor-Faktor yang Mempengaruhi. Jakarta: PT Rineka Cipta.

[31]. Suharnan, (2011). Kreativitas Teori dan Pengembangan. Surabaya: Laros.

[32]. Sugiyono.(2008). Metode Penelitian Pendidikan (Pendekatan Kuantitatif dan Kualitatif $R \& D$. Bandung: Alfabeta.

[33]. Thiagarajan, S.D.(1974). Instructional Development for Training Teacher of Exeptional Children. Minnesota: University Minnesota.

[34]. Torrance, E.P. (1963). Education and The Creative Potential. Minneapolis: The University of Minnesota Press.

[35]. Trianto. (2011). Mendesain Model Pembelajaran Inovatif-Progresif:Konsep, Landasan, dan Implementasinya Pada Kurikulum Tingkat Satuan Pendidikan (KTSP). Jakarta: Kencana Prenada Media Grup.

[36]. Trianto, (2007a). Model Pembelajaran Terpadu dalam Teori dan Praktek, Surabaya: Prestasi Pustaka.

[37]. Utami, A. (2014). Pengembangan Perangkat Pembelajaran IPA Model Inkuiri Dengan Tugas Proyek Untuk Melatihkan Kemampuan Berpikir Kreatif. Surabaya: Program Studi Pendidikan Sains Pasca Sarjana Universitas Negeri Surabaya.

[38]. Woolfolk, A. (2008). Educational Psychology Active Learning Edition. Terjemahan: Soetjipto, dkk. Yogyakarta: Pustaka Pelajar. 